\title{
Sustainable tourism development at the level of health-improving tourism: social-legal aspect
}

\author{
Roza Timakova ${ }^{1, *}$, and Vitali Maksimeniuk ${ }^{2}$ \\ ${ }^{1}$ USUE, 620144 Yekaterinburg, Russian Federation \\ ${ }^{2}$ Faculty of Law of Polotsk State University, 211446, Republic of Belarus
}

\begin{abstract}
The paper considers one of the aspects of sustainable development - sustainable tourism development in accordance with the Sustainable Development Goals aimed at preserving the natural resources of the marine and terrestrial ecosystems. The research of this phenomenon is carried out using the analysis of regulatory legal acts in force in the field of tourism. Since most authors consider the purpose of travel to be one of the generally accepted criteria for dividing into types of tourism, the study was conducted on the basis of one of the most common types of tourism - health-improving tourism, the conceptual apparatus of which is formed under the influence of various conceptual approaches, based on the actual resource potential and features of the promotion of tourist services in the territories of tourist destinations. The proposals on amendments and additions to the existing regulatory legal acts of the Republic of Belarus and the Russian Federation determine the priority of the concept of "sustainable development" in the field of tourism activities.
\end{abstract}

\section{Introduction}

The development of 17 Sustainable Development Goals (SDG) and the subsequent proclamation by the UNO a Decade for Ecosystem Restoration (2021-2030) form a trajectory of effective management of the planet's resources to achieve sustainability of transnational political, economic and socio-cultural relations. Under these conditions, the concept of tourism development (the industry provides jobs for up to $10 \%$ of the world's working population and its effectiveness is largely determined by the complex impact of external factors: preservation and accessibility of ecosystems, the political and epidemiological situation, e.g. the COVID-19 pandemic, development of infrastructure, etc.) is formed in accordance with the relevant sustainable development goals. Thus, the achievement of SDG 14 and SDG 15 aimed at the conservation and rational use of marine and terrestrial ecosystems will allow us to use natural resources for recreation and health improvement of tourists; SDG 8 - to create additional jobs both in tourism and in related industries; within the framework of SDG 12 - as a result of ensuring rational consumption and production patterns, the destructive impact on nature will be reduced. Task 12.b introduces the term "sustainable tourism" (development and implementation of tools for monitoring the impact of sustainable tourism on sustainable development, which

\footnotetext{
*Corresponding author: trt64@mail.ru
} 
contributes to job creation, development of local culture and the production of local products).

According to [1], the following indicators are used to achieve the Sustainable Development Goals in tourism: the change in the number of tourists, the calculation of indicators of permissible tourist loads, preservation of forest and water resources, waste management rules, the level of employment in the tourism sector, the level of economic efficiency, etc.

The main principles of sustainable tourism include the rational use of natural resources of ecosystems, the use of innovative resource-saving technologies in the territory of tourist destinations and specially protected natural areas, the preservation of the natural habitat of fauna and flora, the formation of eco-friendly thinking and a responsible attitude to consumption.

Despite the urbanization of the territories, the growing commercialization and the development of marketing communications, the sustainable development of tourism allows us to develop tourism and, while maintaining its naturalistic basis, ensures the integrity of the destination ecosystems, the maintenance of local traditions and the development of local crafts $[2,3]$.

In the context of the constant transformation of the classification features of healthimproving tourism, the objectives of the research are to study the methodological foundations of health-improving tourism in accordance with the goals of sustainable development and the principles of sustainable tourism, as well as the main regulatory legal acts governing this type of tourism to achieve the following objectives: designing conceptual areas of health-improving tourism and making proposals to change the current legislation on tourism.

\section{Materials and Methods}

The materials for the study were open information resources, scientific and research literature, current regulatory legal acts, methods of observation and theoretical analysis of the methodological foundations of the conceptual apparatus of health tourism in the context of sustainable tourism development, general scientific empirical research methods based on analysis and synthesis as well as the author's approach to the interpretation of the results of the study.

\section{Results and Discussion}

According to the Concept of the Transition of the Russian Federation to Sustainable Development, approved by Presidential Decree No. 440 of April 1, 1996, among the main directions of Russia's transition to sustainable development, there is creation of a legal basis for the transition to sustainable development including the improvement of existing legislation, which defines, in particular, economic mechanisms for regulating natural resources and environmental protection.

The concept of the National Strategy for Sustainable Development of the Republic of Belarus until 2035, developed in 2018, defines the development of domestic and inbound tourism with optimal use of natural resources among the priority areas of activity in tourism until 2035. The strategic objectives of the state policy are: in the field of environmental protection to ensure environmentally friendly conditions for the life of society; in the field of conservation and rational use of natural potential to use effectively natural resources and ensure the sustainable functioning of ecosystems. 
The terminology used in the tourist industry requires certain systematization and structuring through the classification of its types. The existing classification of types of tourism is based on the main principles and features. In particular, the UNWTO Thesaurus on Tourism and Leisure Activities contains up to 200 terms that reflect the essence of international tourism [4]. A comparative analysis of the legal acts on tourism in force in the CIS countries also shows the existing differences in the classification of types of tourism.

At the same time, most researchers in this field, as well as the national legislation of various countries, single out the purpose of a tourist trip as one of the criteria.

As O. N. Vikulova notes, the purposes of trips are among the main signs of tourism [5]. It should be borne in mind that a particular trip would not have taken place without the main purpose [6]. In the theory of tourism, the classification of tourism depending on the purpose of the trip is called a "functional" classification.

Therefore, the purpose of the trip is one of the essential criteria for dividing into types of tourism and is important at various levels:

- public (customs declaration, border and migration control, etc.);

- private-law (the purpose of the trip and the types of services provided in the civil contract for the provision of tourist services).

Based on this criterion, the number of types of tourism includes "health-improving tourism", which is considered an independent type of tourism at the doctrinal, regulatory and practical levels. However, in relation to the conceptual apparatus of health-improving tourism, there has not been developed a single concept, which leads to the use of different terms: "medical tourism", " medical and health-improving tourism", "health-improving tourism", "spa tourism"," sports and health tourism "[7], wellness, medical wellness [8], as well as "recreational" (recreational and health-improving), the latter as part of medical and health-improving tourism, provides only preventive and health-improving programs in the absence or minimal representation of the therapeutic component [9].

It is not always possible to define the concept of "health-improving tourism" at the regulatory level.

In particular, in the legislation of the Russian Federation on tourism, the definition of the concept under consideration is contained only in the Concept of the Federal Target Program " Development of domestic and inbound tourism in the Russian Federation (20192025)", approved by Government Decree No. 872-r of May 5, 2018, as "a trip for recreation and restoration of physical health, providing medical and recreational, preventive, recreational and beach services". Other regulatory legal acts either only mention healthimproving tourism, or provide the concept of a similar category - " medical and healthimproving tourism".

The concept of development of the tourist industry of the Republic of Kazakhstan until 2023, approved by the decree of the Government of the Republic of Kazakhstan of 30.06.2017 No. 406 contains the definition of "beach tourism" as a trip to improve one's health, and the Law of the Republic of Kazakhstan "On Tourist activities in the Republic of Kazakhstan" of June 13, 2001 No. 211-II gives the definition of medical tourism.

The legislation of the Republic of Belarus does not currently include a definition of the concept of "health-improving tourism", although it is mentioned in various regulatory legal acts, in particular, in the State Program " Hospitable Belarus" for 2021-2025, approved by Resolution of the Council of Ministers of the Republic of Belarus No. 58 of 29.01.2021; in the National Strategy for Sustainable Socio-economic Development of the Republic of Belarus until 2030, approved by the Presidium of the Council of Ministers of the Republic of Belarus (prot. dated May 2, 2017, No. 10).

The analysis of the opinions of various authors, as well as the existing regulatory legal acts of various states, allows us to identify the signs that are most often found in characterizing this type of tourism. 
First, these are the purposes of a tourist trip, which may include: the formation of a healthy lifestyle, the preservation of health, the prevention of diseases, the restoration of health, recreation.

Second, these are objects of tourist infrastructure visited by tourists to achieve healthimproving goals - sanatorium-resort and health-improving organizations.

Based on the above, for the purposes of this study, the following formulation of healthimproving tourism is proposed: "a trip of individuals to health resort and wellness organizations for recreation, health resort treatment and receiving health services aimed at preventing diseases, preserving and restoring health".

From the point of view of the target audience, for practical purposes, it is possible to distinguish children's, sports and social health-improving tourism characterized by sustainable development due to full or partial state funding.

Thus, in the Federal Law "On the Basics of Tourist Activities in the Russian Federation", social tourism is defined as "a trip subsidized from funds allocated by the state for social needs" and is allocated to a separate type of tourism [10], which indicates the inseparable symbiotic development of different types of tourism.

Various international legal documents pay great attention to social tourism. As noted in the Manila Declaration on Tourism of 1980, "social tourism is a goal that society should strive for in the interests of less well-off citizens in the exercise of their right to rest" [11] Article 13 of the Montreal Declaration, adopted in 1996 by the General Assembly of the International Bureau of Social Tourism, states that any tourist organization that ensures the accessibility of tourism to the maximum number of people, without limiting tourism to the sole purpose of maximizing profit [12], can belong to the social tourist movement.

In the professional environment, the following terms that are considered synonymous with social tourism or more closely reflect its meaning are used:

- tourism for all or tourism without barriers;

- inclusive;

- accessible or accessible to all

Taleb Rifai, as UNWTO Secretary General, noted that: "Accessibility is a central element of any socially responsible and sustainable tourist policy. This is a prerequisite for human rights and an exceptional business opportunity. In addition, we must recognize that affordable tourism will benefit not only people with disabilities or special needs, but all of us will benefit from it ". [13]

Children's tourism includes trips and excursions for children, educational and recreational children's tours, vacation rest in health centers and camps, sports children's tourism, trips to the cities of the country, the CIS countries and Europe [14]. Unlike many other types of tourism, children's tourism is distinguished not by the purpose of the trip, but by the target audience. As one of the mass types of tourism, children's tourism performing educational and other socially significant functions [15] is an effective means of improving health and educating the younger generation [16].

In relation to this type of tourism, the experience of the Russian Federation is indicative. There is registered the Union of Organizers of Children's Active Tourism, which is a nonprofit organization. It was formed to promote health improvement and comprehensive development of children and youth [17]. The Federal Law of the Russian Federation "On the Basics of Tourist Activities in the Russian Federation" gives the concept of the definition of "children's tourism".

The register of sports in the Republic of Belarus, approved by the Order of the Minister of Sports and Tourism of the Republic of Belarus of March 27, 2015 No. 129, defines "sport tourism" as a separate sport.

According to [18], based on the Unified All-Russian Sports Classification (approved by the order of the Ministry of Sports of the Russian Federation of 6.09.2013 No. 715), 
"rafting","mountaineering" and "orienteering" can be attributed to a subcategories of sport tourism [18], in the Republic of Belarus the last two categories are included in the current Register of Sports as independent sports.

Despite the fact that sports and tourism industries are interconnected, the legislation on tourism of the Russian Federation and the Republic of Belarus does not represent such types of tourism as "sports and recreation" or "sports", while in Article 5 of the Law of the Republic of Uzbekistan "On Tourism", "sports tourism" is fixed as an independent type of tourism, and in the Law of Tajikistan "On Tourism" this type of tourism is called "mountain sports tourism".

Pessot E., Spoladore D., Zangiacomi A., Saco M state that effective use of natural resources is a key determinant for the development of health-improving tourism.[19].

Health-improving tourism, considered in the context of the restrictive measures of the movement of tourists between individual states or regions in the context of the ongoing COVID-19 pandemic, allows us to solve the problems of the economic and social character of separate territories, aimed at creating investment attractiveness and surplus budgeting.

For example, the formation of innovative approaches in the work of medical and health institutions, e.g. eco-medical schemes that include agro - and aqua-ecological technologies (safe food, water supply, waste-free production, etc., provides year-round utilization of these institutions and a certain barrier to the spread of epidemiological diseases [20].

Based on the fact that the UNWTO defines accessible tourism as one of the main directions of sustainable tourism characterized by safety and comfort for tourists without any restrictions [21], in 2021 rehabilitation and relaxation trips, short-term trips within regions to restore interpersonal communications and neosocialization in society are becoming important. A number of authors [22] define the need for a strategic approach to improving the health of the population on the basis of active types of tourism and through the development of environmental factors. Yankevich E. M. speaks about the possibility of restoring physical and mental strength of a person in regional recreational zones [23].

The new version of the Model Law "On Tourist Activities", adopted by Resolution No. 42-14 of the Inter-Parliamentary Assembly of the CIS Member States on April 16, 2015, contains one of the most detailed definitions of the concept of "tourist resources". Among the listed resources, it is possible to distinguish the following types of resources that will be relevant to sustainable development in the context of health-improving tourism:

- natural and climatic, recreational, social and household resources;

- objects of tourist interest that can help restore and develop the physical strength of tourists, maintain their normal life activities;

- medical and recreational areas;

- resorts.

\section{Conclusions}

Since the exploitation of these resources is inextricably linked to the Sustainable Development Goals, in particular, SDG 12, SDG 14 and SDG 15, the initial task is to amend and supplement the legislation regulating health-improving tourism and spa treatment including provisions on the sustainable development of relevant activities and preservation of natural resources used by tourists to receive health services.

Based on the above, it is proposed:

1. Ch. 1 Article 1 of the Federal Law of the Russian Federation of 23.02.1995 No. 26-FZ

"On Natural Healing Resources, Health-improving Localities and Resorts" should be worded as follows: "A territory is recognized as a health-improving locality or resort depending on its significance by the Government of the Russian Federation, the relevant executive authority of a subject of the Russian Federation, or a local 
self-government body on the basis of special health resort, hydrogeological documents and studies, the sustainable development goals for the relevant ecosystems taken into account ".

2. Chapter III of the National Strategy for Tourism Development of the Republic of Belarus until 2035, approved by the decision of the Interdepartmental Expert Coordination Council for Tourism under the Council of Ministers of the Republic of Belarus of October 7, 2020 "Strategic goals, objectives, targets, indicators, principles of strategy implementation" should be amended in the following way: instead of "The implementation of the Strategy is based on the principles" to write "The implementation of the Strategy is based on the principle of "sustainable tourism development".

\section{References}

1. S.V. Smirnov, Akad. publ., 2, 57 (2020)

2. V. R.M. Torres, A.S. Lorenzo, S. J. Castro et al., J. of sc. and techn. pol. man., 4(10), 905 (2019)

3. K. Werner, K-M. Griese, S. Bosse, J. of sust. able tour., 0021 (2020)

4. Secret. of State for Tour. of France and World Tour. Organ. (WTO), 802 (2001)

5. O.N. Vikulova, ModernLib.ru

6. Dep. po ek. i soc. vopr. Sekret. OON (2010) http://unstats.un.org

7. A.M. Vetitnev, A.A. Torgasheva, NIU ITMO, 4, 86 (2014)

8. S.L. Mozokina, Izv. Sankt-Pet. gos. ek. un., 2, 42 (2014)

9. N.A. Savel'eva, R.V. Kolesnikov, T.V. SHmeleva, Nauka i obr.: hoz. i ek.; predpr.; pr. i upr, 7(122), 7 (2020)

10. V.G. Ajrapetyan, Gum. nauchn. vestn., 1, 9 (2020)

11. Man. dekl. po mir. tur. (1980) http://docs.cntd.ru

12. M.M. Skoreev, D.V. Zaloznaya, Terra Ec., 4, 257 (2006)

13. N.M. Borisenko-Klepach, Prosv. pravozashch. uchr. (2016)

14. O. M. Golikova, Serv. v Ros.i za rub., 8(35), 10 (2012)

15. E. V. Aigina, N. I. Tul'skaya, Sovr. issl. soc. probl., 10(54), 506 (2015)

16. A. A. Tel'nova, E. G. Telicheva, Uch. zam. TOGU, 8(3), 17 (2017)

17. Soyuz org. detsk. akt. turizma, http://sodat.ru/

18. G.I. Kalinin, Tur.: pr. i ek., 2(61), 3 (2017)

19. E. Pessot, D. Spoladore, A. Zangiacomi, M. Saco, Nat. Res. Health Tour.: asyst. lit. rev., 13(5), 2661 (2021)

20. G.A. Simonyan, A.L. Tumanova, Sovr. nauch. mys., 3, 152 (2020)

21. V. Maksimeniuk, R. Timakova, E3S Web of Conf., 208, 06004 (2020)

22. A.S. Basyuk, A.E. Kolesnik, Mezhdunar. nauch.-prakt. konf. (2020)

23. E.M. YAnkevich, Pravo. Ek. Psih., 4(20), 61 (2020) 